\title{
Diminished Expression of CD40 Ligand by Activated Neonatal T Cells
}

\author{
Shigeaki Nonoyama, *1 Laurie A. Penix, * Caroline P. Edwards," David B. Lewis, * Sukeyuki Ito,' Alejandro Aruffo, ${ }^{\text {"I }}$ \\ Christopher B. Wilson, ** and Hans D. Ochs* \\ * Department of Pediatrics, ${ }^{\ddagger}$ Department of Immunology, ${ }^{8}$ Department of Biological Structure, University of Washington, Seattle, \\ Washington 98195; "Bristol-Myers Squibb Pharmaceutical Research Institute, Seattle, Washington 98121; and 'Department of \\ Pediatrics, Tokyo Medical and Dental University, Tokyo 113, Japan
}

\begin{abstract}
CD40 and CD40 ligand (gp39) mediate contact-dependent T-B cell interaction. We determined the expression of CD40 ligand by activated neonatal $T$ cells and the response of neonatal B cells when activated through CD40. Although expression of CD40 ligand peaked simultaneously in both activated adult and neonatal cells, neonatal $T$ cells expressed significantly less CD40 ligand surface protein and mRNA than adult $\mathrm{T}$ cells. Activated thymocytes also expressed far less CD40 ligand than adult $T$ cells. Consistent with these results, activated neonatal $T$ cells exhibited less helper function than activated adult $T$ cells. Neonatal $T$ cells primed and restimulated in vitro expressed CD40 ligand in amounts comparable with adult $T$ cells and provided $B$ cell help more effectively. This suggests that the poor expression of CD40 ligand reflects antigenic naiveté rather than an intrinsic defect of neonatal $T$ cells. Neonatal B cells cultured with soluble CD40 ligand (sgp39) and IL-10 produced IgM in amounts comparable with adult cells, but much less IgG and IgA. Nevertheless, neonatal B cells were capable of proliferation and class switching, since sgp39 and $\mathrm{L}-4$ induced proliferation and IgE production comparable to adult $B$ cells and production of modest amounts of IgG. Together, these results indicate that diminished CD40 ligand expression, along with decreased production of lymphokines, may be responsible, at least in part, for the transient immunodeficiency observed in human neonates. (J. Clin. Invest. 1995. 95:66-75.) Key words: CD40 ligand expression • immunologic memory • immunodeficiency of the newborn • immunoglobulin synthesis • immunoglobulin switching
\end{abstract}

\section{Introduction}

Human neonates are deficient in the ability to mount an efficient antibody response to antigenic challenge (1). This appears to be a result of immaturity both of neonatal $B$ cells and neonatal $\mathrm{T}$ cells, as well as a lack of antigen exposure. Neonatal B cells continue to exhibit a fetal pattern of surface immunoglobulins, bearing either IgG or IgA with both IgM and IgD simultane-

Address correspondence to Dr. Hans D. Ochs, Department of Pediatrics, RD-20, School of Medicine, University of Washington, Seattle, WA 98195. Phone: 206-543-3207; FAX: 206-543-3184.

Received for publication 3 December 1993 and in revised form 31 August 1994.

J. Clin. Invest.

(c) The American Society for Clinical Investigation, Inc. $0021-9738 / 95 / 01 / 0066 / 10 \quad \$ 2.00$

Volume 95, January 1995, 66-75 ously, suggesting that they have not completed class switching, which would result in deletion of the $\mathrm{CH} \mu$ and $\mathrm{CH} \delta$ regions (1). Polyclonal activation with Staphylococcus aureus (2) or transformation by Epstein-Barr virus (3) induces neonatal B cells to secrete only small amounts of $\operatorname{IgM}$ and no $\operatorname{IgA}$ or IgG. Further, an efficient antibody response by B cells requires contact-dependent interaction with activated $T$ cells and exposure to $\mathrm{T}$ cell-derived cytokines. Activated neonatal $\mathrm{CD}^{+}{ }^{+} \mathrm{T}$ cells are deficient in their capacity to provide such help to either neonatal or adult B cells (2). This may reflect in part the diminished capacity of neonatal $\mathrm{T}$ cells to produce cytokines such as IL-4 and IFN- $\gamma(4-7)$. However, relatively little is known regarding the mechanism underlying the inability of neonatal $\mathrm{T}$ cells to provide contact-dependent help.

One receptor/ligand pair known to be important for induction of a full B cell response is CD40 and CD40 ligand (gp39). ${ }^{1} \mathrm{~B}$ cells constitutively express CD40, and signals delivered via CD40 induce $B$ cell proliferation $(8,9)$, differentiation, and isotype switching in the presence of coactivation signals $(10$, 11). B cells stimulated with anti-CD40 and IL-4 proliferate and differentiate by switching Ig class production from IgM to IgE (11-14). In contrast, IL-10 promotes immunoglobulin secretion primarily without inducing class switching, since $\mathrm{IgD}^{+}$ (naive) B cells cultured in the presence of anti-CD40 and IL10 produce only IgM, and $\mathrm{IgD}^{-}$(mature) B cells secrete IgG, $\operatorname{IgA}$, and IgM (15). A soluble recombinant form of CD40 ligand ( sgp39), if added to a B cell culture system, has an effect similar to anti-CD40 mAb on B cell proliferation and Ig synthesis (10, $16,17)$. The dependence of normal $B$ cell function upon the presence of functional $\mathrm{T}$ cells reflects, at least in part, the expression of the ligand for CD40, gp39, by activated human T cells (18-21). The importance of this interaction is underscored by the finding that the molecular defect responsible for the hyper IgM syndrome is a functionally defective CD40 ligand, resulting in the failure of B cells to switch from IgM to IgA and IgG production (16, 22-25). Furthermore, a decrease in CD40 ligand expression by activated $\mathrm{T}$ cells from patients with common variable immunodeficiency may be responsible, in part, for the hypogammaglobulinemia and antibody deficiency observed in these patients (26).

In this study, we examined the hypothesis that the immaturity in immunoglobulin production, particularly of classes other than IgM, by neonates reflects not only the limited capacity of neonatal $\mathrm{T}$ cells to produce critical cytokines, but also a diminished ability to provide cognate help to B cells through CD40. We observed that neonatal $\mathrm{T}$ cells and CD4 single-positive thymocytes expressed decreased amounts of CD40 ligand, while

1. Abbreviations used in this paper: CD40-Ig, human CD40 coupled with $\mathrm{Fc}$ domain of human $\mathrm{IgG}_{1}$; gp39, CD40 ligand; sgp39, soluble CD40 ligand. 
in vitro stimulation of neonatal B cells with sgp39 and cytokines induced normal proliferation, IgM production, and isotype switching to $\operatorname{IgE}$ and IgG. These findings suggest that decreased CD40 ligand expression by activated T cells may be a major cause of immature B cell function in the neonate. Furthermore, since induction of CD40 ligand expression was observed after in vitro priming of neonatal $\mathrm{T}$ cells, the diminished inducibility of CD40 ligand expression by activated neonatal $\mathrm{T}$ cells may result from the lack of stimulation of the prenatal immune system by exogenous antigens.

\section{Methods}

Cell preparations. Heparinized blood samples were obtained either from healthy adult volunteers or from the placental segment of the umbilical cord. Peripheral blood mononuclear cells (PBMC) were prepared by Ficoll-Hypaque gradient centrifugation. To further purify B cells, T cells were removed from mononuclear cells by twice rosetting with aminoethylisothiuronium bromide (Sigma Chemical Co., St. Louis, MO) treated sheep red blood cells (27). Natural killer cells and monocytes were removed by treating cells with $5 \mathrm{mM}$ L-leucine methyl ester hydrochloride (Sigma Chemical Co.) in serum-free RPMI 1640 as described (28). The B cell-enriched populations obtained consisted of $>90 \% \mathrm{~B}$ cells $\left(\mathrm{CD}_{2} 0^{+}\right)$and $<1 \% \mathrm{~T}$ cells $\left(\mathrm{CD}^{+}\right)$as determined by flow cytometry.

T cells were purified from PBMC by complement-mediated negative selection using T cell Lymphokwik (One Lambda, Los Angeles, CA) and anti-CD16 mAb FC-1. Human thymic tissue removed during cardiothoracic surgery was minced, sieved, and purified by Ficoll-Hypaque. The age of thymic tissue donors ranged from 6 mo to 4 yr. The CD4enriched subset of peripheral blood T lymphocytes and CD4 singlepositive thymocytes were obtained after incubation of cells with OKT8 monoclonal antibody (kindly provided by J. A. Ledbetter, Bristol-Myers Squibb Pharmaceutical Research Institute, Seattle, WA) and complement. These procedures have been described previously and routinely yield preparations of $>90 \%$ purity $(6,29)$.

In vitro culture of mitogen-primed $T$ cells. $\mathrm{T}$ cells purified from peripheral blood were cultured at $2.5 \times 10^{6} \mathrm{cells} / \mathrm{ml}$ in RPMI 1640 medium (BioWhittaker, Inc., Walkersville, MD) supplemented with $10 \%$ fetal bovine serum (Hyclone Labs, Logan, UT), $25 \mathrm{mM}$ Hepes, $2 \mathrm{mM}$ L-glutamine, $100 \mathrm{U} / \mathrm{ml}$ penicillin, $100 \mu \mathrm{g} / \mathrm{ml}$ streptomycin, and $20 \mu \mathrm{g} / \mathrm{ml}$ gentamicin (complete medium) plus either $1 \mu \mathrm{g} / \mathrm{ml}$ PHA (Sigma Chemical Co.) or $3 \mu \mathrm{g} / \mathrm{ml} \mathrm{Con} \mathrm{A} \mathrm{(Sigma} \mathrm{Chemical} \mathrm{Co.)} \mathrm{and}$ $0.5 \mathrm{ng} / \mathrm{ml}$ PMA (Sigma Chemical Co.), in media containing $5 \mathrm{ng} / \mathrm{ml}$ recombinant human IL-2 (a gift from Steve Gillis, Immunex Corp., Seattle, WA) and $5 \mathrm{U} / \mathrm{ml}$ purified IL-2 (Boehringer Mannheim Biochemicals, Indianapolis, IN) in $5 \% \mathrm{CO}_{2}$ at $37^{\circ} \mathrm{C}$ for $3 \mathrm{~d}$. Preliminary experiments indicated that the combination of recombinant and purified IL-2 resulted in better $\mathrm{T}$ cell proliferation and survival. Cells were then washed, resuspended in complete medium plus $10 \mathrm{ng} / \mathrm{ml}$ recombinant IL-7 (a gift from Steve Ziegler, Immunex Corp.), and incubated for 2 $\mathrm{d}$ to allow quiescence of the cells, as defined by diminuation of CD69 surface expression to baseline levels seen in unstimulated freshly isolated cells.

Assay of CD40 ligand expression. Freshly isolated or in vitro primed $\mathrm{T}$ cells and purified thymocytes were cultured at $1-3 \times 10^{6} \mathrm{cells} / \mathrm{ml}$ in complete medium with $10 \mathrm{ng} / \mathrm{ml}$ PMA and $1.0 \mu \mathrm{g} / \mathrm{ml}$ ionomycin for $8 \mathrm{~h}$, or in kinetics experiments, for 1-30 h. Cells were then washed, resuspended in RPMI with $2 \%$ fetal calf serum, and stained for $30 \mathrm{~min}$ at $4^{\circ} \mathrm{C}$ with either $10-25 \mu \mathrm{g} / \mathrm{ml}$ of a soluble fusion protein consisting of the extracellular domain of human CD40 coupled with the $\mathrm{Fc}$ domain of human IgG I $_{1}$ CD40-Ig), or $10-25 \mu \mathrm{g} / \mathrm{ml}$ of L6 or Leu-8, isotypematched fusion proteins as described previously (16) (reagents provided by Bristol-Myers Squibb Pharmaceutical Research Institute). After washing, cells were incubated with FITC-conjugated goat anti-human IgG (Tago Inc., Burlingame, CA) for $30 \mathrm{~min}$ at $4^{\circ} \mathrm{C}$. For dual color staining, cells were further stained with PE-conjugated monoclonal Abs (anti-CD45RA, anti-CD45RO, or anti-CD4) after adding human IgG to block the FITC-conjugated anti-human IgG. After washing, cells were resuspended in $0.1 \% \mathrm{NaN}_{3}, 0.1 \%$ BSA. Fusion protein binding was determined by FACScan ${ }^{8}$ (Becton Dickinson, Mountainview, CA). Other mAbs used in this study include anti-CD4, anti-CD45RA (Coulter Corp., Hialeah, FL), and anti-CD45RO (Tago Inc.)

Northern blotting. Total cellular RNA was isolated from resting and activated $\mathrm{T}$ lymphocytes and freshly isolated CD4 single-positive thymocytes using Trisolv reagent (Biotecx Laboratories Inc., Houston, TX) and then electrophoresed and transferred as described (29). A 300bp HindIII restriction fragment of the CD40 ligand cDNA, a 1.6-kb EcoR1 fragment containing the CD69 cDNA (30) (provided by Steve Ziegler), and a 245-bp EcoR1/HindIII fragment of the CD3 $\delta$ chain cDNA were labeled by the random hexamer primer method (Pharmacia LKB Biotechnology, Piscataway, NJ) and used as described (31). Blots were stripped between hybridizations by boiling $10 \mathrm{~min}$ in buffer containing $200 \mathrm{mM}$ Tris ( $\mathrm{pH} 8.0$ ), $0.1 \%$ SDS, and $2 \mathrm{mM}$ EDTA ( $\mathrm{pH}$ 8.0). Autoradiographic analysis was carried out by the PhosphorImager Facility of the Markey Molecular Medicine Center at the University of Washington, then quantitated, corrected for background, and expressed as the ratio of the CD40 ligand integrated density divided by the signal generated by the $\mathrm{CD} 69$ or $\mathrm{CD} 3 \delta$ probe.

$B$ cell culture. To induce B cell proliferation, $2.5 \times 10^{4}$ purified B cells per well were cultured in complete medium in the presence of 50 $\mu \mathrm{l}$ of supernatant from COS cells transfected with CD40 ligand (sgp39) as described (32) and $\mathrm{IL}-4(100 \mathrm{U} / \mathrm{ml})$ for $4 \mathrm{~d}$ in 96-well round-bottom microculture plates at a final volume of $200 \mu \mathrm{l}$ per well, followed by a 16-h pulse with $1 \mu \mathrm{Ci}\left[{ }^{3} \mathrm{H}\right]$ thymidine. To induce Ig production, 2.5 $\times 10^{4}$ purified $\mathrm{B}$ cells per well were cultured in 96 -well round-bottom microculture plates in $200 \mu \mathrm{l}$ of complete medium, in the presence of sgp39 (1:4 dilution, as above), IL-4 (100 U/ml), or IL-10 $(10 \mathrm{ng} / \mathrm{ml})$. We used sgp39, rather than anti-CD40, to achieve a more physiologic stimulation of B cells. Dose-response experiments indicated that IL10 at $10 \mathrm{ng} / \mathrm{ml}$ induces optimal Ig production by normal adult B cells. Purified human rIL-4 and rIL-10 were gifts from Dr. K. W. Moore (DNAX, Palo Alto, CA). After $12 \mathrm{~d}$ of culture, supernatants were collected and tested for Ig levels.

Immunoglobulin determination. The concentrations of IgG, IgA, IgM, IgE, and IgG subclasses in the supernatants of cultured cells were measured by ELISA. For IgG, IgM, IgA, and IgE determination (14), 96-well microculture plates were coated with either goat anti-human IgG, IgA, or IgM (Organon Teknika Corp./Cappel, West Chester, PA) or a mixture of equal amounts of two mouse $\mathrm{IgG}_{1}$ monoclonal antihuman IgE antibodies (CIA-E-4.15 and CIA-E-7.12, kindly provided by Dr. Andrew Saxon, University of California, Los Angeles, CA) in appropriate dilution and kept overnight at $4^{\circ} \mathrm{C}$. After blocking the wells with PBS containing $1 \%$ BSA, serially diluted test samples or standards (purified from human sera) were added to each well and cultured at $37^{\circ} \mathrm{C}$ for $2 \mathrm{~h}$. IgG, IgA, and IgM standards were purchased from Kent Laboratories (Kent, WA). IgE standard was purchased from Pharmacia AB (Uppsala, Sweden). After washing, secondary antibodies were added and plates were incubated for $2 \mathrm{~h}$ at $37^{\circ} \mathrm{C}$. Secondary antibodies used were as follows: alkaline phosphatase-conjugated goat anti-human IgG (Cappel Laboratories), alkaline phosphatase-conjugated goat anti-human IgA (Sigma Chemical Co.), alkaline phosphatase-conjugated goat anti-human IgM (Sigma Chemical Co.), or biotin-conjugated goat anti-human IgE (Kirkegaard \& Perry Laboratories, Inc., Gaithersburg, MD). For IgE measurement, plates were subsequently incubated with alkaline phosphatase-conjugated extravidin (Sigma Chemical Co.). The substrate solution contained $p$-nitrophenyl phosphate disodium $1 \mathrm{mg} / \mathrm{ml}$ (Sigma Chemical Co.) in carbonate buffer, $\mathrm{pH}$ 9.8, with $10 \mathrm{mM} \mathrm{MgCl}{ }_{2} 6 \mathrm{H}_{2} \mathrm{O}$.

Assay of $T$ cell helper activity. Freshly isolated or mitogen-primed $\mathrm{T}$ cells obtained from adult peripheral blood or cord blood were cultured at $1-3 \times 10^{6}$ cells $/ \mathrm{ml}$ in complete medium with $10 \mathrm{ng} / \mathrm{ml}$ PMA and $1.0 \mu \mathrm{g} / \mathrm{ml}$ ionomycin for $8 \mathrm{~h}$. Cells were then fixed with freshly made $1 \%$ paraformaldehyde for $10 \mathrm{~min}$ (21). After washing five times, an 


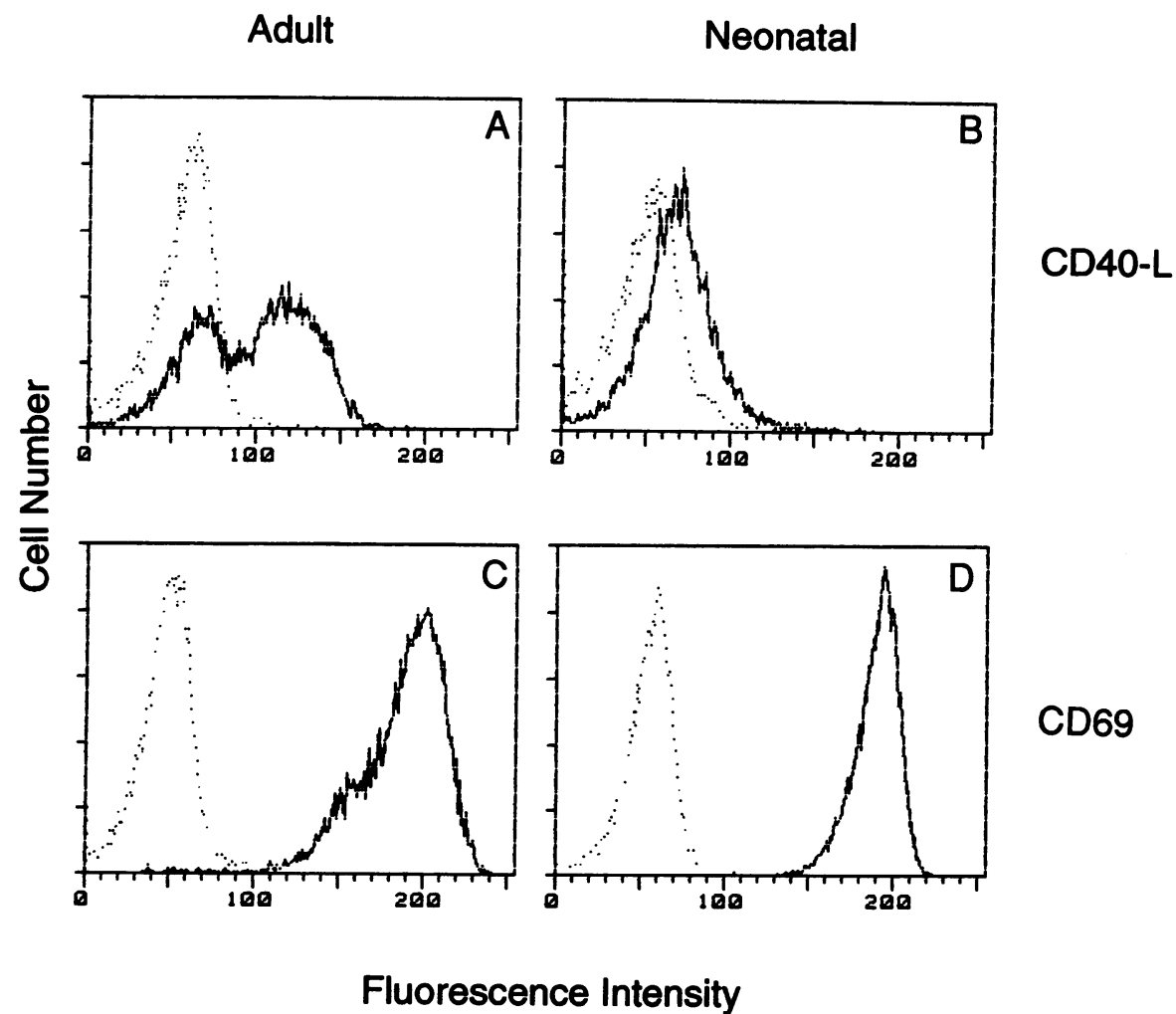

Figure 1. Diminished CD40 ligand (CD40$L$ ) expression by neonatal $T$ cells. Purified $T$ cells obtained from normal adult peripheral blood $(A$ and $C)$ or cord blood $(B$ and $D)$ were cultured in the presence of PMA ( 10 $\mathrm{ng} / \mathrm{ml})$ and ionomycin $(1 \mu \mathrm{g} / \mathrm{ml})$ for $8 \mathrm{~h}$. Cells were stained with CD40-Ig (solid lines, $A$ and $B$ ), control fusion protein L6 (dashed lines, $A$ and $B$ ), anti-CD69 (solid lines, $C$ and $D$ ), or mouse Ig of the same isotype as anti-CD69 (dashed lines, $C$ and $D$ ). aliquot of fixed $\mathrm{T}$ cells was added to the $\mathrm{B}$ cell culture system described above and analyzed for helper activity. In brief, $2.5 \times 10^{4} \mathrm{~B}$ cells obtained from unrelated cord blood were cultured in 96-well roundbottom microculture plates in the presence of IL-4 $(100 \mathrm{U} / \mathrm{ml})$ and 2.5 $\times 10^{4}$ fixed $T$ cells for $12 \mathrm{~d}$. IgE concentrations in the culture supernatants were measured by ELISA.

Statistics. Data were compared using the Student's $t$ test, MannWhitney $U$ Test, and StatView 4.01 software (Abacus Concepts Inc., Berkeley, CA).

\section{Results}

Diminished expression of CD40 ligand by activated neonatal $T$ cells. CD40 ligand expression by purified neonatal and adult $T$ cells activated with PMA and ionomycin for $8 \mathrm{~h}$ was assessed by a CD40-Ig binding assay. A representative experiment is shown in Fig. 1. The proportion of neonatal $\mathrm{T}$ cells expressing CD40 ligand $(9.0 \%$, Fig. $1 \mathrm{~B})$ was less than that of adult $\mathrm{T}$ cells $(54.0 \%$, Fig. $1 A)$, which were processed in parallel. This diminished expression was reflected in both fluorescence intensity and percentage of positively stained cells. Diminished CD40 ligand expression was not due to a global defect of activation, since the early $\mathrm{T}$ cell activation marker, CD69, was expressed equally well by neonatal $(99.4 \%$, Fig. $1 D)$ and adult T cells $(98.4 \%$, Fig. $1 C$ ). When analyzed as a group, the percentage of neonatal $\mathrm{T}$ cells expressing CD40 ligand (geometric mean, $12.6 \%$; $97 \%$ confidence limits, $6.5-24.5 \%, n=12$ ) was significantly less $(P<0.005$, Mann-Whitney $U$ Test $)$ than that of adult $\mathrm{T}$ cells (geometric mean, $49.5 \%$; $97 \%$ confidence limits, $37.1-66.2 \%, n=12$ ). As apparent in Fig. 1, the CD40 ligand ${ }^{\text {hi }}$ population was usually absent in activated neonatal $\mathrm{T}$ cells. Similar results were obtained when whole blood mononuclear cells were studied (data not shown). The peak of CD40 ligand expression in both neonatal and adult $\mathrm{T}$ cells was observed after $6-8 \mathrm{~h}$ of activation. Throughout the culture period, neonatal $\mathrm{T}$ cells expressed lower amounts of CD40 ligand than adult $\mathrm{T}$ cells, while the level of CD69 was comparable (Fig. 2).

Purified neonatal and adult $\mathrm{T}$ cells were activated and double

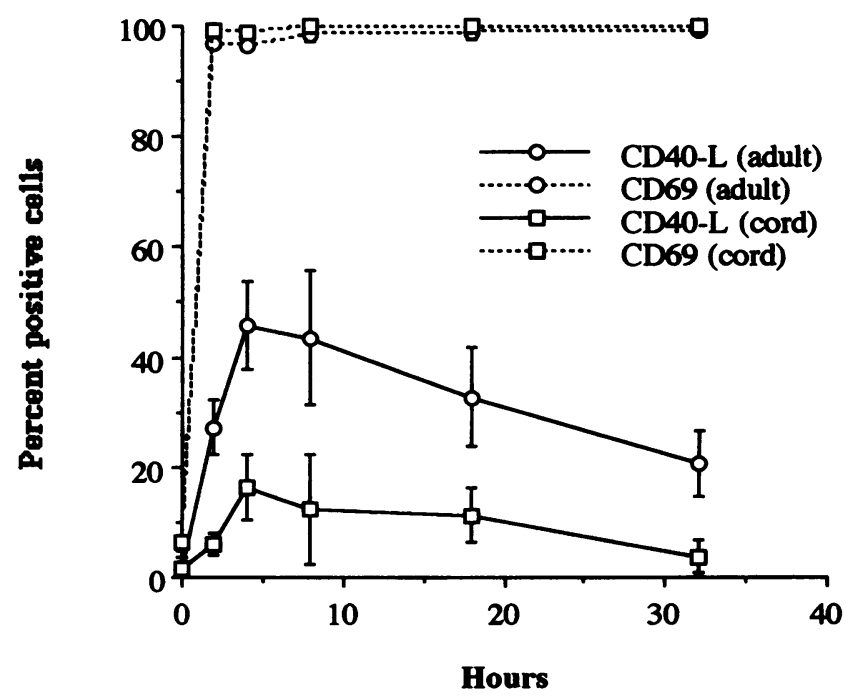

Figure 2. Kinetic study of CD40 ligand expression by adult and neonatal $\mathrm{T}$ cells. Adult or neonatal $\mathrm{T}$ cells were cultured in the presence of PMA $(10 \mathrm{ng} / \mathrm{ml})$ and ionomycin $(1 \mu \mathrm{g} / \mathrm{ml})$ for 2-33 h. CD40 ligand (CD40$L$ ) or CD69 expression was determined by flowcytometry, as described in Fig. 1. Dots and error bars indicate mean and SD calculated from five samples. 


\section{Adult}
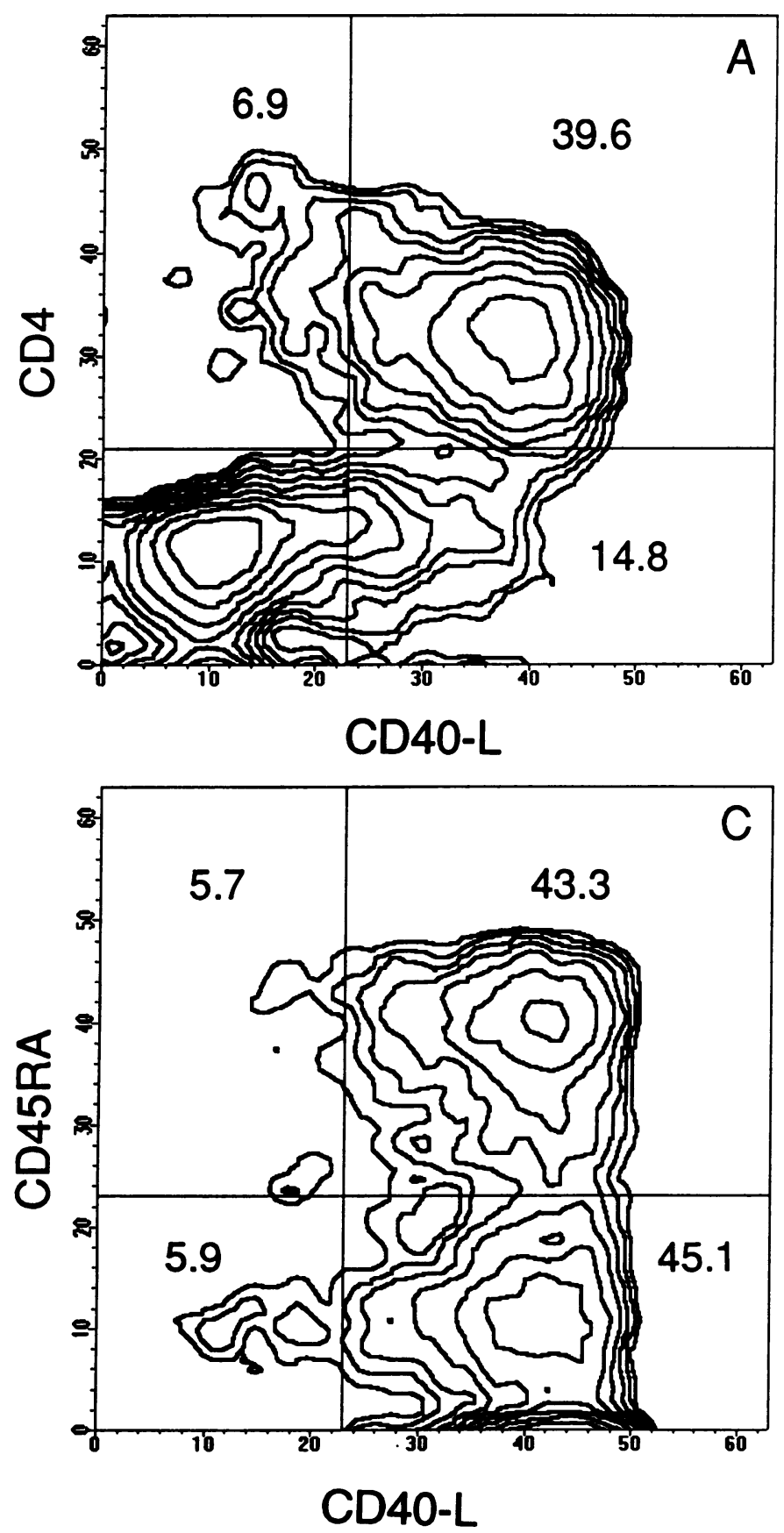

Neonatal
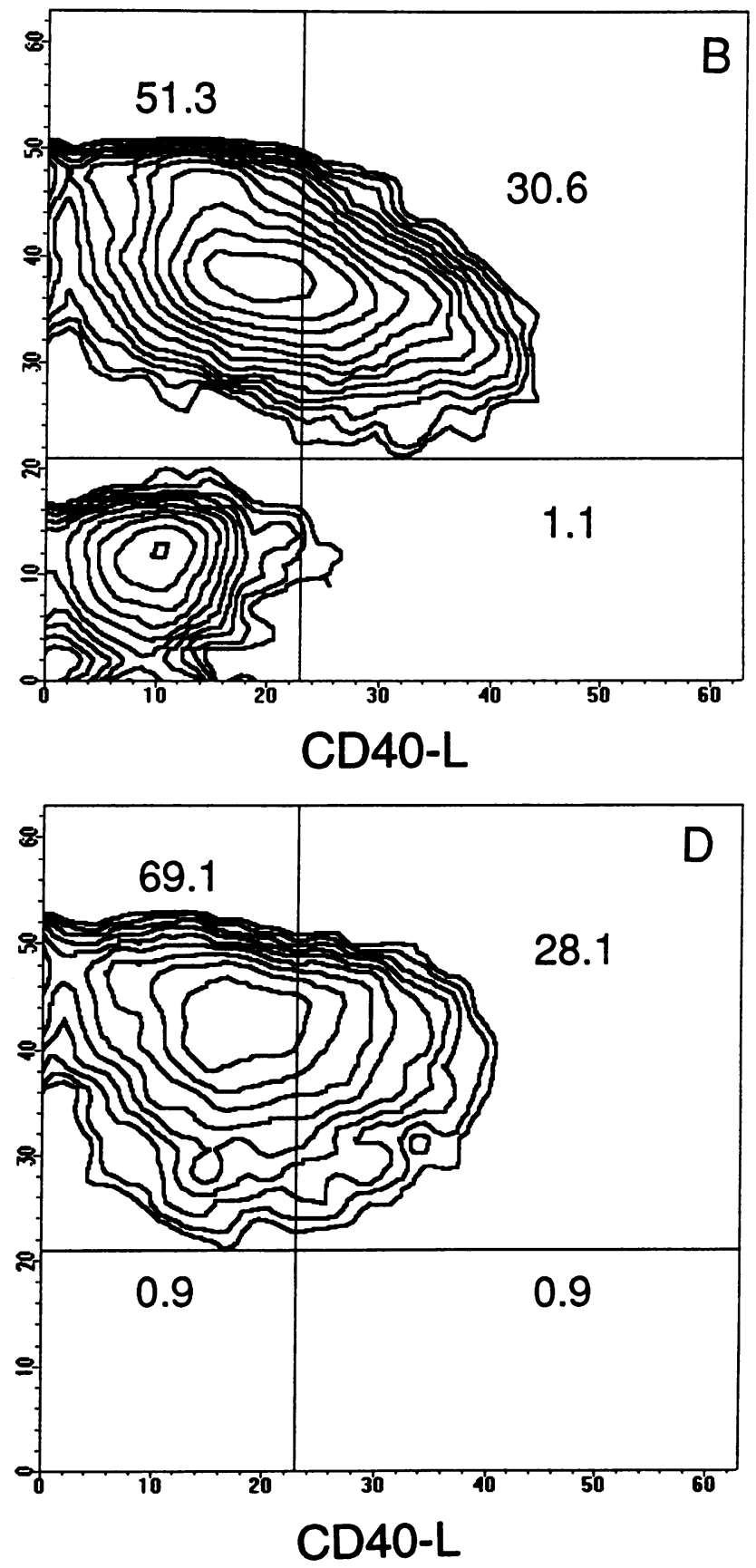

Figure 3. Two-color flowcytometric analysis of adult and neonatal $\mathrm{T}$ cells and purified $\mathrm{CD}^{+}{ }^{+} \mathrm{T}$ cells. In the upper panels, $\mathrm{T}$ cells isolated from adult peripheral blood $(A)$ and neonatal cord blood $(B)$ were activated (cultured in the presence of PMA [10 $\mathrm{ng} / \mathrm{ml}]$ and ionomycin [1 $\mu \mathrm{g} / \mathrm{ml}]$ for $8 \mathrm{~h}$ ) and then stained with CD40-Ig and anti-CD4. In the lower panel, CD4 ${ }^{+} \mathrm{T}$ cells purified from adult $(C)$ and neonatal $(D) \mathrm{T}$ cells were similarly activated and then stained with CD40-Ig and anti-CD45RA.

stained by anti-CD4 and CD40-Ig (Fig. 3, $A$ and $B$ ). More than $80 \%$ of adult $C D 4^{+} \mathrm{T}$ cells expressed CD40 ligand. Small populations of $\mathrm{CD}^{-}{ }^{-}$adult $\mathrm{T}$ cells expressed CD40 ligand (Fig. $3 A$ ). In contrast, only $37 \%$ of activated neonatal $\mathrm{T}$ cells positive for CD4 expressed CD40 ligand, and these cells expressed less CD40 ligand, as demonstrated by the intensity of fluorescent staining, than the activated adult $\mathrm{CD} 4^{+} \mathrm{T}$ cells. Neonatal CD4 ${ }^{-}$ $\mathrm{T}$ cells did not express CD40 ligand (Fig. $3 \mathrm{~B}$ ).
$\mathrm{CD} 4{ }^{+} \mathrm{T}$ cells, enriched by negative selection, were double stained with anti-CD45RA mAb and CD40-Ig. CD40 ligand was equally expressed by $\mathrm{CD} 45 \mathrm{RA}^{+}$and $\mathrm{CD}^{+} 5 \mathrm{RA}^{-}$adult $\mathrm{CD}^{+} \mathrm{T}$ cells (Fig. $4 \mathrm{C}$ ). Concordantly, when adult $\mathrm{CD} 4^{+}$ cells were stained with anti-CD45RO $\mathrm{mAb}$, both $\mathrm{CD}^{2} 5 \mathrm{RO}^{+}$ and $\mathrm{CD}^{4} \mathrm{RO}^{-}$subsets expressed similar amounts of CD40 ligand (data not shown). As previously noted, most neonatal $\mathrm{CD}^{+} \mathrm{T}$ cells were $\mathrm{CD}^{+} 5 \mathrm{RA}^{+}(6,33,34)$. While $88 \%$ of the 
Oh
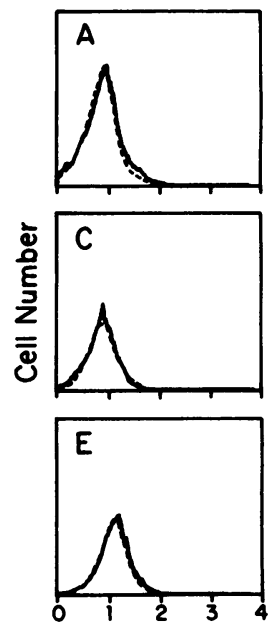

Log Fluorescence Intensity
$8 \mathrm{~h}$
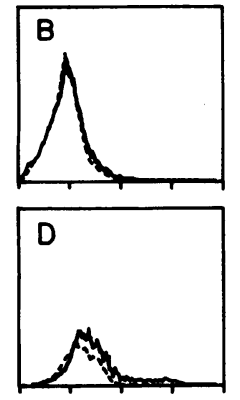

$F$

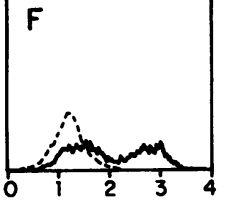

Adult

T cells

Figure 4. CD40 ligand expression by thymocytes. Unselected thymocytes ( $A$ and $B), \mathrm{CD} 4$ single-positive enriched thymocytes ( $C$ and $D)$, and peripheral blood adult $\mathrm{T}$ cells $(E$ and $F)$ were cultured in the presence of PMA $(10 \mathrm{ng} / \mathrm{ml})$ and ionomycin $(1 \mu \mathrm{g} / \mathrm{ml})$ for $0 \mathrm{~h}(A, C$, and $E)$ or $8 \mathrm{~h}(B, D$, and $F)$. Cells were stained with CD40-Ig (solid lines) and control fusion protein Leu-8 (dashed lines).

cells within adult $\mathrm{CD}^{2} 5 \mathrm{RA}^{+} \mathrm{CD}^{+}{ }^{+}$subset expressed CD40 ligand, only $29 \%$ of the cell within neonatal CD45RA ${ }^{+} \mathrm{CD}^{+}$ subset expressed CD40 ligand (Fig. $3 \mathrm{D}$ ). Similar results were obtained by three independent experiments (data not shown).

Diminished expression of CD40 ligand by activated thymocytes. CD40 ligand expression was not detected in resting whole thymocytes or total thymocytes activated with PMA and ionomycin for $8 \mathrm{~h}$ (Fig. $4, A$ and $B$ ) or 4 and $16 \mathrm{~h}$ (data not shown). Enriched CD4 single-positive thymocytes that were activated with PMA and ionomycin for $8 \mathrm{~h}$ (Fig. $4 \mathrm{D}$ ) or 4 and $16 \mathrm{~h}$ (data not shown) demonstrated a small induction of CD40 ligand expression relative to unstimulated cells (Fig. $4 C$ ). The intensity of CD40-Ig binding by activated CD4 single-positive thymocytes varied slightly ( $n=5$, data not shown); Fig. 4 shows the preparation with the greatest CD40-Ig binding. Clearly CD40 ligand expression by activated CD4 single-positive thymocytes (17\%, Fig. $4 \mathrm{D}$ ) was markedly lower than that seen with adult $T$ cells processed in parallel (52\%, Fig. $4 F$ ). In contrast to CD40-Ig binding, CD69 expression by thymocytes and adult $\mathrm{T}$ cell was comparable (data not shown).

CD4O ligand mRNA is diminished in activated neonatal $T$ cells and thymocytes. Northern analysis of total cellular RNA from both neonatal and adult $T$ cells activated with PMA and ionomycin revealed that CD40 ligand mRNA peaked at $2 \mathrm{~h}$ of stimulation and was diminished in neonatal $\mathrm{T}$ cells at each time point studied (Fig. 5, $A$ and $B$ ); CD40 ligand mRNA was not detected in unstimulated $\mathrm{T}$ cells. Similarly, activated thymocytes and CD4 single-positive thymocytes had diminished expression of CD40 ligand mRNA (data not shown). Because CD69 expression was equivalent between adult and neonatal T cells by FACS $₫$ analysis (Fig. 2 ) and produced equal mRNA signal for all activation time points analyzed (data not shown), data are expressed as a ratio of the integrated densities of CD40 ligand and CD69 signal for each lane to allow correction for variability in RNA loading. Selected blots were also hybridized
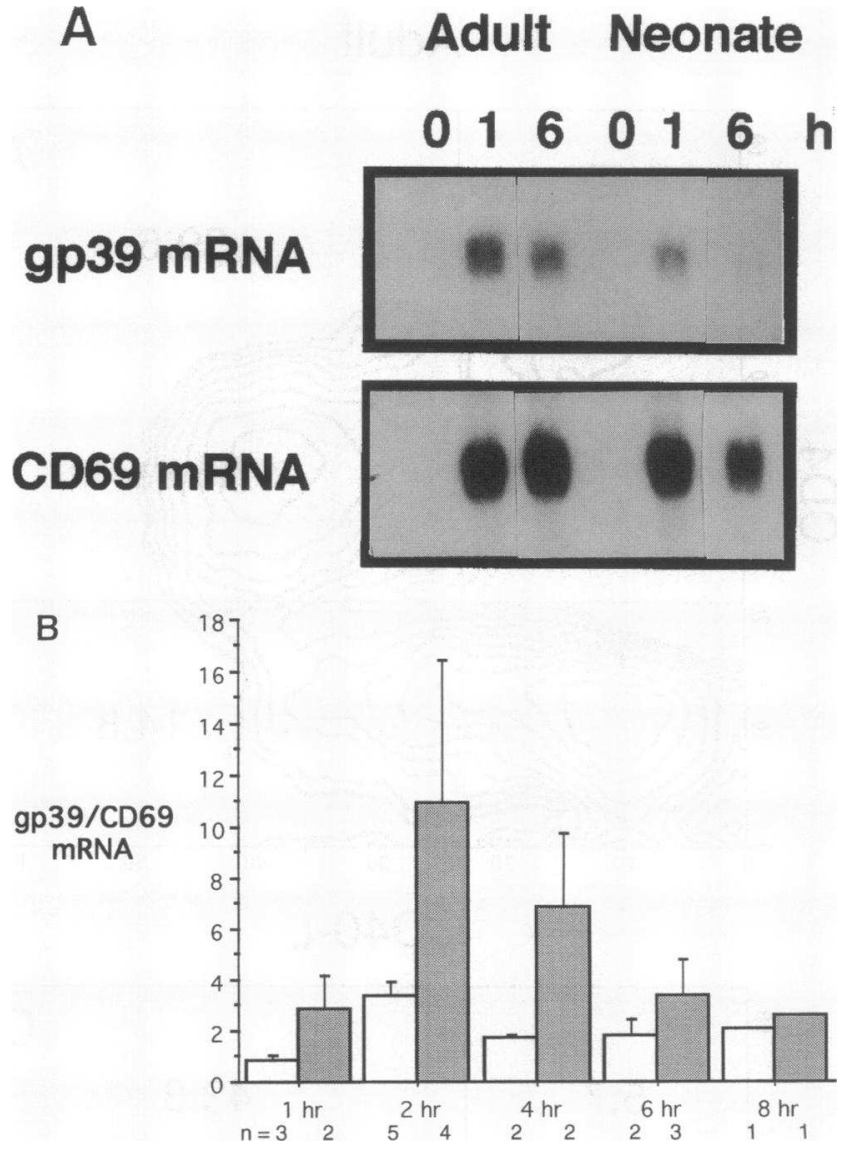

Figure 5. Northern analysis of adult and neonatal T cell CD40 ligand mRNA. (A) A representative blot of $5 \mu \mathrm{g}$ total RNA per lane from adult and neonatal $\mathrm{T}$ cells (unstimulated, $\mathrm{O} \mathrm{h}$ ) and stimulated with PMA $(10 \mathrm{ng} / \mathrm{ml})$ and ionomycin $(1 \mu \mathrm{g} / \mathrm{ml})$ for 1 or $6 \mathrm{~h}$. All blots were hybridized sequentially with CD40 ligand cDNA probe (upper panel) and CD69 cDNA probe (lower panel). $B$ contains a graphical representation of the mean \pm standard error of the mean of CD40 ligand mRNA from adult (shaded bars) and neonatal T cells (white bars) activated with the above concentrations of PMA and ionomycin for the designated time periods. Results are expressed as a ratio of the corrected integrated density for CD40 ligand divided by that for CD69 per lane. The number of data points for each time period is indicated below the graph.

with the CD3 $\delta$ chain probe; when CD40 ligand expression was estimated as a ratio to $C D 3 \delta$, the results were similar to those obtained by comparing CD40 ligand and CD69 expression (data not shown).

Induction of CD40 ligand by in vitro mitogen priming of neonatal $T$ cells. Previous studies have shown that in vitro primed neonatal $\mathrm{T}$ cells acquire the ability to provide help for B cell differentiation (35) and to secrete additional lymphokines, e.g., IL-4 and IFN- $\gamma(6,7)$. We studied in parallel neonatal and adult $\mathrm{T}$ cells from five individuals each, cultured in the presence of Con A, PMA, and IL-2 for $3 \mathrm{~d}$, washed, and allowed to quiesce for an additional $2 \mathrm{~d}$ in the presence of IL-7. Cells were then restimulated with PMA and ionomycin. The proportion of activated neonatal $T$ cells expressing CD40 ligand by FACS $₫$ analysis $(2.9 \%$, Fig. $6 B)$ increased with in vitro priming $(50.5 \%$, Fig. $6 \mathrm{D})$ to a level comparable with that of either freshly isolated, activated adult $\mathrm{T}$ cells $(35.6 \%$, Fig. $6 \mathrm{~A})$ or 


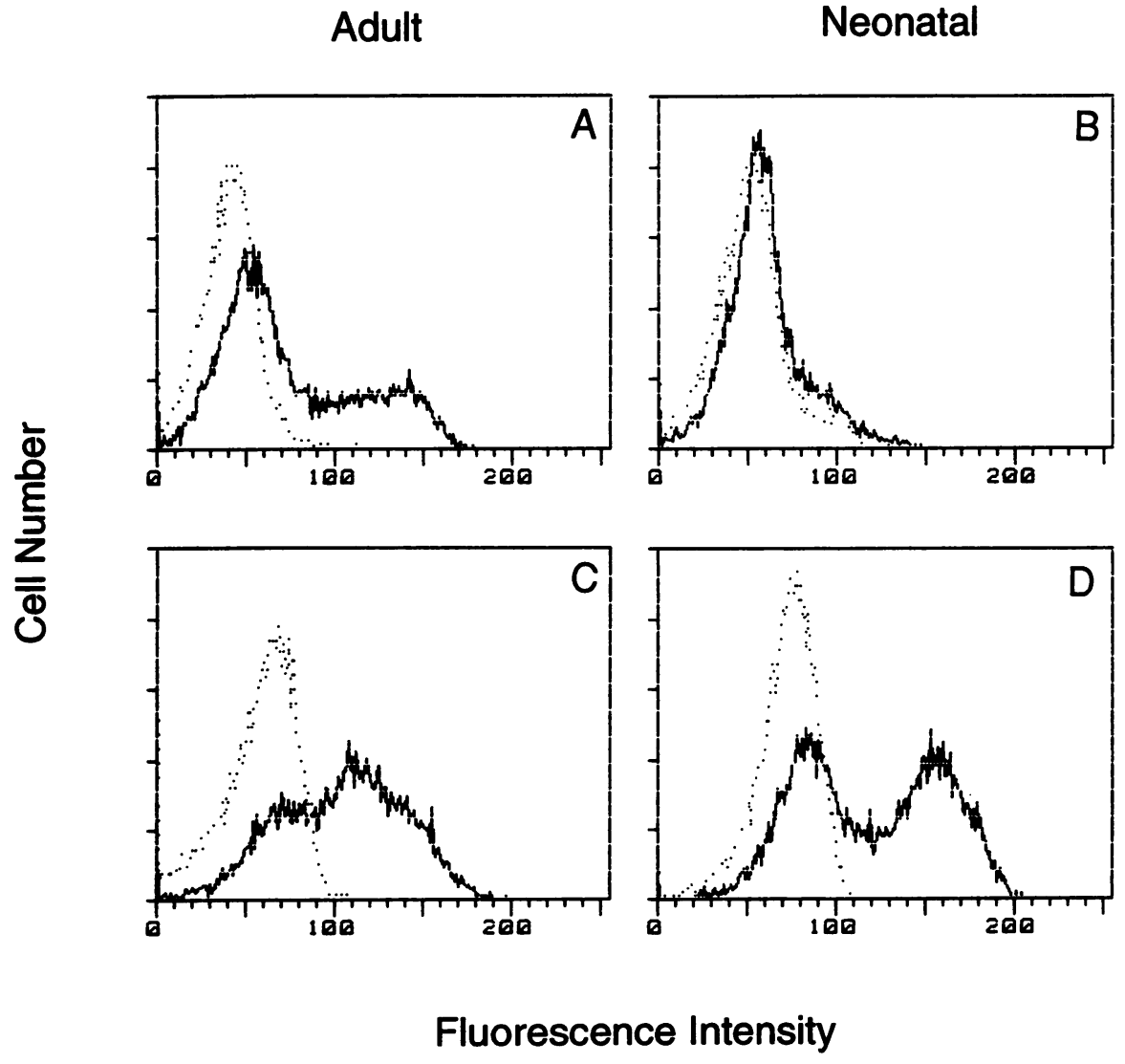

Figure 6. Previous mitogen stimulation primes neonatal T cells for CD40 ligand expression upon restimulation. Adult or neonatal T cells were cultured with Con A ( $3 \mu \mathrm{g} /$ $\mathrm{ml})$ and PMA $(0.5 \mathrm{ng} / \mathrm{ml})$ in media containing IL-2 for $3 \mathrm{~d}$. After washing, cells were cultured in the presence of human IL-7 (10 $\mathrm{ng} / \mathrm{ml}$ ) for $2 \mathrm{~d}$. These primed $\mathrm{T}$ cells (adult $[C]$, neonate $[D])$ and freshly isolated $\mathrm{T}$ cells (adult $[A]$, neonate $[B]$ ) from the same individuals were cultured with PMA (10 ng/ $\mathrm{ml})$ and ionomycin $(1 \mu \mathrm{g} / \mathrm{ml})$ for $8 \mathrm{~h}$, then stained with CD40-Ig to measure CD40 ligand expression. This figure contains results of one representative experiment. Similar results were obtained from four additional pairs of adult and neonatal donors. primed, activated adult T cells $(57.0 \%$, Fig. $6 C$ ). Priming cells in the presence of PHA gave similar results (data not shown).

$T$ helper activity by neonatal $T$ cells. Freshly isolated $T$ cells and mitogen-primed $\mathrm{T}$ cells were assayed for their helper activity. $T$ cells obtained from adults and neonates were activated with PMA and ionomycin, fixed with paraformaldehyde, and examined for their ability to induce IgE production if cocultured with neonatal B cells in the presence of IL-4. Fig. 7 shows representative results from one of four independent experiments. Neonatal T cells induced significantly less IgE than adult T cells if freshly isolated cells were studied $(P<0.05$, Student's $t$ test). However, if mitogen-primed cells were examined, neonatal $\mathrm{T}$ cells induced IgE amounts comparable with those induced by the freshly isolated adult $\mathrm{T}$ cells.

$B$ cell proliferation and IgE production in response to sgp39 and IL-4 is comparable in both neonatal and adult $T$ cells. Purified B cells obtained from neonatal and adult peripheral blood were cultured without $(-)$ or with $(+) \operatorname{sgp} 39$ and IL-4; cell proliferation was assessed after $4 \mathrm{~d}$ of culture (Fig. $8 \mathrm{~A}$ ) and IgE production was assessed after $12 \mathrm{~d}$ of culture (Fig. 8 $B$ ). Difference between the $\left[{ }^{3} \mathrm{H}\right]$ thymidine uptake (mean $\pm \mathrm{SD}$ ) observed by activated neonatal B cell $(36,055 \pm 18,772, n=8)$ and adult $B$ cells $(39,909 \pm 22,372, n=8)$ is statistically not significant $(P>0.1)$. Similarly, there is no statistical difference $(P>0.1)$ between the amounts of IgE produced by neonatal B cells $(18,803 \pm 12,913 \mathrm{pg} / \mathrm{ml}, n=15)$ and by adult $B$ cells $(21,379 \pm 14,772 \mathrm{pg} / \mathrm{ml}, n=15)$.

Production of $\operatorname{IgG}, A$, and $M$ by adult and neonatal $B$ cells. Peripheral blood B cells obtained from normal adult volunteers produce IgG, IgA, and IgM when cultured in the presence of sgp39 and IL-10 (Fig. 9, top). Cord blood B cells from 8 out of 13 neonates produced amounts of IgM comparable with adult B cells, and 5 produced lower but detectable levels of IgM. In contrast, the amounts of IgG and IgA produced by stimulated neonatal B cells were consistently and markedly lower than those produced by adult B cells. B cells obtained from 10 out of 13 neonates failed to produce detectable amounts of $\mathrm{IgG}$, and 6 out of 13 failed to produce detectable levels of IgA (Fig. 9 , bottom). Since IL-10 (at a concentration of $10 \mathrm{ng} / \mathrm{ml}$ ), unlike IL-4, has little, if any, capacity to induce Ig class switch (15), these results are consistent with a paucity of neonatal B cells that have undergone switching to $\operatorname{IgG}$ or $\operatorname{IgA}$ in vivo $(1,3)$. As shown in Table I, neonatal B cells failed to produce IgG if cultured in the presence of sgp39 and IL-10, although they did produce low amounts of IgG, compared with adult B cells, if cultured in the presence of sgp39 and IL-4, a lymphokine that has been shown to facilitate Ig class switching (12-14). The addition of IL-10 increased IgG production by neonatal B cells induced with sgp39 and IL-4, although not nearly to the degree seen with the adult B cells. The IgG produced by neonatal B cells cultured in the presence of IL-4 contained all IgG subclasses (data not shown).

\section{Discussion}

In this study, we found that activated neonatal $\mathrm{T}$ cells express decreased amounts of CD40 ligand compared with adult $T$ cells. This decreased expression was demonstrated both by a CD40Ig binding assay, which determines the functional CD40 ligand protein levels on the cell surface, and by Northern analysis of 


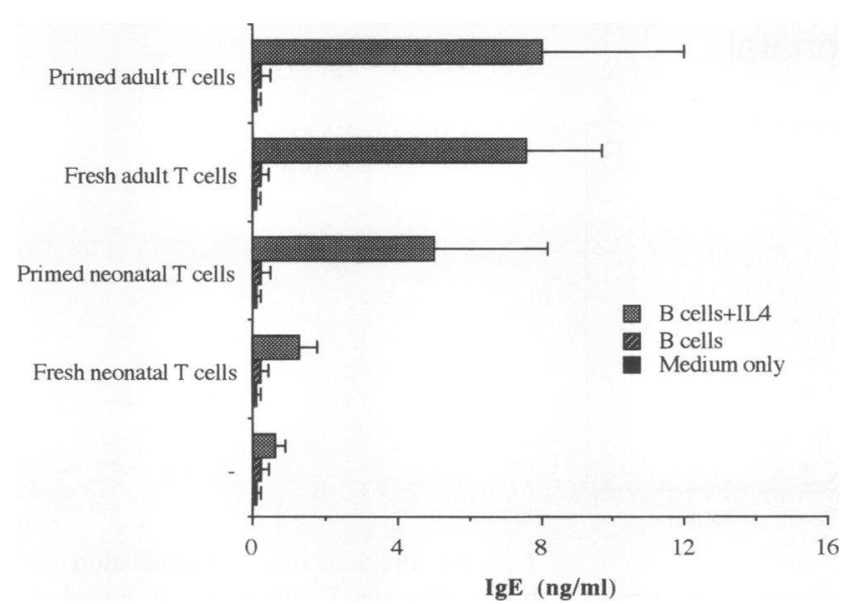

Figure 7. Helper function by neonatal and adult $\mathrm{T}$ cells. $\mathrm{T}$ cells primed as described in the legend of Fig. 6 and freshly isolated T cells from the same individuals were cultured with PMA $(10 \mathrm{ng} / \mathrm{ml})$ and ionomycin $(1 \mu \mathrm{g} / \mathrm{ml})$ for $8 \mathrm{~h}$ and then fixed with $1 \%$ paraformaldehyde. 2.5 $\times 10^{4}$ thus fixed T cells were cultured with $2.5 \times 10^{4}$ neonatal B cells obtained from unrelated donors in the presence of IL-4 $(100 \mathrm{U} / \mathrm{ml})$ for $12 \mathrm{~d}$. IgE concentration in the culture supernatant was measured by ELISA. Results are shown as a mean and SD of triplicate culture. Results in the absence of $\mathrm{T}$ cells are shown at the bottom (-). Similar results were obtained with each of four pairs of adult and neonatal donors.

CD40 ligand mRNA. The level of CD40 ligand expression by neonatal $\mathrm{T}$ cells was consistently lower than that of the adult $\mathrm{T}$ cells, though the peak expression of CD40 ligand on the cell surface was observed at 6-8 h after the initiation of both adult and neonatal $\mathrm{T}$ cell activation. In contrast, the $\mathrm{T}$ cell activation marker, CD69, was expressed at similar levels by activated neonatal and adult $\mathrm{T}$ cells after stimulation, suggesting that the decreased CD40 ligand expression by neonatal T cells was not due to a global activation defect. Since CD40 ligand is believed to play a major role in the contact-dependent $T$ cell help, we then compared the helper activity of the neonatal and adult $T$ cells. To exclude the difference of the ability to produce cytokines between adult and neonatal $\mathrm{T}$ cells, activated $\mathrm{T}$ cell were fixed and added to the B cell culture in the presence of IL-4. Consistent with the study of CD40 ligand expression, we found that neonatal $\mathrm{T}$ cells exhibited significantly less helper activity to induce IgE production by $\mathrm{B}$ cells than adult $\mathrm{T}$ cells. These results indicate that decreased CD40 ligand expression is directly responsible for the depressed helper activity by activated neonatal $T$ cells.

To further clarify the defective expression of CD40 ligand by neonatal $\mathrm{T}$ cells, we stained activated $\mathrm{CD} 4^{+} \mathrm{T}$ cells with CD40-Ig and anti-CD45RA. As previously reported, most neonatal $\mathrm{CD}^{+}{ }^{+} \mathrm{T}$ cells were CD45RA ${ }^{+}$(naive) cells, while about half of adult $\mathrm{CD}^{+}$were $\mathrm{CD}^{+} 5 \mathrm{RA}^{-}$(memory) cells $(4,6,7$, 35 ). Whereas $>80 \%$ of activated adult $\mathrm{CD}_{45 \mathrm{RA}^{+} \mathrm{CD}^{+} \mathrm{T}}$ cells expressed CD40 ligand, CD40 ligand expression by activated neonatal $\mathrm{CD} 45 \mathrm{RA}^{+} \mathrm{CD}^{+}{ }^{+} \mathrm{T}$ cells was $<30 \%$. This observation suggests that neonatal $\mathrm{CD} 4 \mathrm{RA}^{+} \mathrm{CD}^{+} \mathrm{T}$ cells are different in some respect from adult CD45RA ${ }^{+} \mathrm{CD} 4{ }^{+} \mathrm{T}$ cells. Other phenotypic and functional differences between adult and neonatal CD45RA ${ }^{+} \mathrm{CD}^{+} \mathrm{T}$ cells have been reported. CD38, a membrane molecule characteristic of immature lymphoid cells
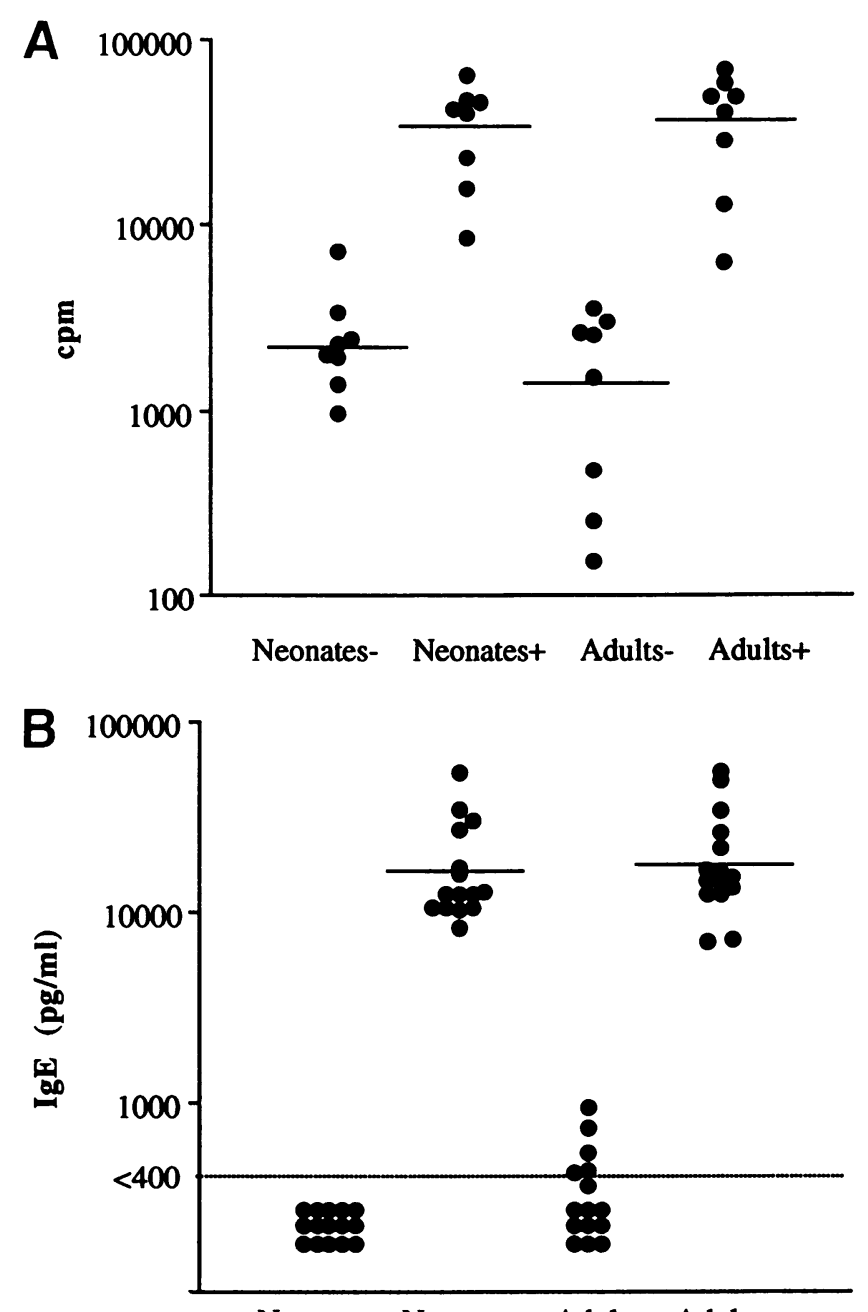

Neonates- Neonates+ Adults- Adults+

Figure 8 . Equivalent proliferation and IgE production by adult and neonatal B cells cultured with sgp39 and IL-4. (A) Purified B cells obtained from adult peripheral blood $(n=7)$ or cord blood $(n=8)$ were cultured in the presence $(+)$ or absence $(-)$ of sgp39 (1:4 dilution of CD40 ligand transfected COS cell supernatant) and IL-4 (100 U/ $\mathrm{ml}$ ) for $4 \mathrm{~d}$. $\left[{ }^{3} \mathrm{H}\right]$ Thymidine uptake is shown; horizontal bars indicate geometric means. $(B)$ IgE synthesis by adult $(n=15)$ or neonatal ( $n$ $=15)$ B cells cultured in the presence $(+)$ or absence $(-)$ of sgp39 (1:4) and IL-4 (100 U/ml) for $12 \mathrm{~d}$. IgE concentrations in culture supernatants were measured by ELISA with a lower limit of detectability of $400 \mathrm{pg} / \mathrm{ml}$. Horizontal bars indicate geometric means.

(e.g., thymocytes), is expressed by the majority of neonatal CD45RA ${ }^{+} \mathrm{CD}^{+} \mathrm{T}$ cells but not by adult CD45RA ${ }^{+} \mathrm{CD}^{+} \mathrm{T}$ cells (35). Neither neonatal nor adult CD45RA ${ }^{+} \mathrm{CD}^{+}{ }^{+} \mathrm{T}$ cells provide efficient help for $\mathrm{B}$ cell immunoglobulin production $(35,36)$. However, neonatal CD45RA ${ }^{+} \mathrm{CD}^{+} \mathrm{T}$ cells, but not adult CD45RA ${ }^{+} \mathrm{CD}^{+} \mathrm{T}$ cells, suppress $\mathrm{B}$ cell responses (35). From these observations, it is suggested that, although neither cell produces cytokines critical to Ig production, neonatal CD45RA ${ }^{+} \mathrm{CD}^{+} \mathrm{T}$ cells are more immature than the adult $\mathrm{CD}_{45 \mathrm{RA}^{+} \mathrm{CD}^{+} \mathrm{T} \text { cells, and that a portion of neonatal }}$ $\mathrm{CD}_{4} \mathrm{RA}^{+} \mathrm{CD}^{+}$cells may mature with age without losing CD45RA expression (35). Alternatively, the adult CD45RA ${ }^{+}$ $\mathrm{CD}^{+}{ }^{+}$population may contain a subset that reverted from 


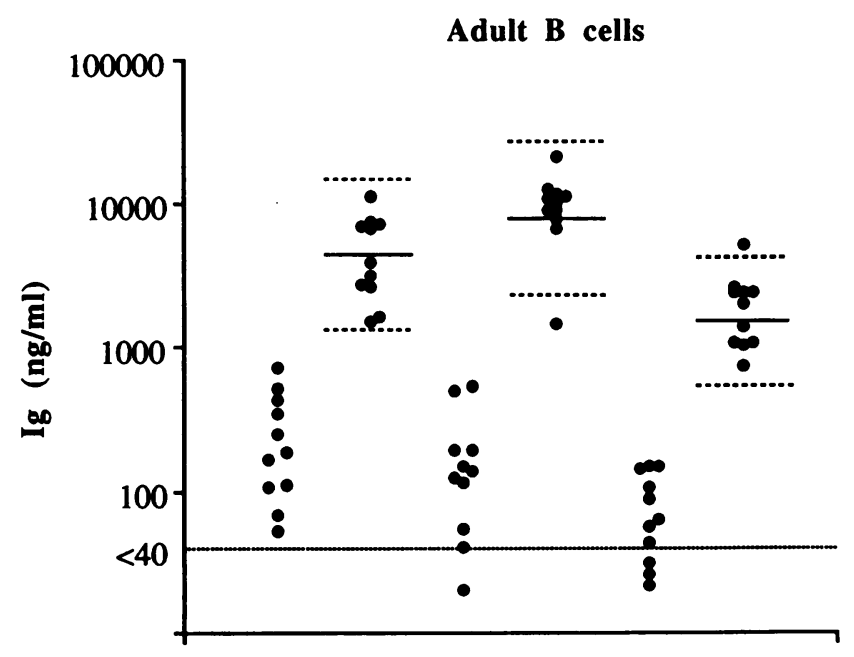

IgG- IgG+ IgA- IgA+ IgM- IgM+

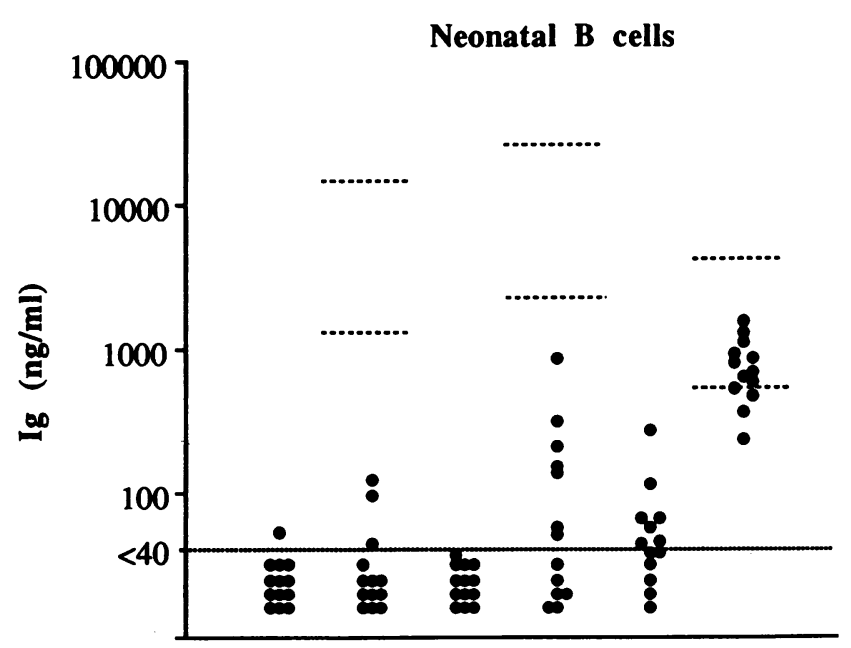

IgG- IgG+ IgA- IgA+ IgM- IgM+

Figure 9. Diminished Ig production by neonatal B cells cultured with sgp39 and IL-10. Adult $(n=11)$ and neonatal $(n=13)$ B cells were cultured in the presence $(+)$ or absence $(-)$ of sgp39 (1:4) and IL-10 $(10 \mathrm{ng} / \mathrm{ml})$ for $12 \mathrm{~d}$. IgG, IgA, and IgM concentrations in the culture supernatants were determined by ELISA with a lower limit of detectability of $40 \mathrm{ng} / \mathrm{ml}$. Solid horizontal bars indicate geometric means and dashed bars indicate $95 \%$ confidence intervals of the $\mathrm{Ig}$ production by adult B cells.

CD45RA ${ }^{-} \mathrm{CD}^{+}{ }^{+} \mathrm{T}$ cells, since $\mathrm{CD} 45 \mathrm{RA}^{-}$cells may, under certain conditions, reexpress CD45RA after Ag stimulation (37).

Although the precise mechanism is not well understood, exposure to exogenous antigen is believed to play an important role in the maturation of the neonatal immune system. Conversion from CD45RA ${ }^{+} \mathrm{CD}^{+}$(naive) $\mathrm{T}$ cells into CD45RO ${ }^{+}$ cells by antigen exposure was demonstrated by the observation that $\mathrm{CD} 4{ }^{+} \mathrm{CD} 45 \mathrm{R}^{\text {high }} \mathrm{T}$ cells transferred to nude mice convert to $\mathrm{CD} 4{ }^{+} \mathrm{CD} 45 \mathrm{R}^{10} \mathrm{~T}$ cells by in vivo immunization with sheep red blood cells and mediate antigen-specific recall IgG responses (38). Priming of adult or neonatal CD45RA ${ }^{+} \mathrm{CD}^{+}$ $\mathrm{T}$ cells by polyclonal activation in vitro appears to mimic in vivo antigen exposure. Most neonatal and adult CD45RA ${ }^{+} \mathrm{T}$
Table I. Effect of IL-4, IL-10, and sgp39 on IgG Production by $B$ Cells

\begin{tabular}{|c|c|c|c|c|}
\hline \multirow[b]{2}{*}{ Donors } & \multicolumn{4}{|c|}{ IgG (ng/ml) } \\
\hline & $\begin{array}{l}\text { B cells } \\
\text { alone }\end{array}$ & $\begin{array}{l}+ \text { sgp39 } \\
+ \text { IL10 }\end{array}$ & $\begin{array}{l}+ \text { sgp39 } \\
+\mathrm{IL4}\end{array}$ & $\begin{array}{c}+ \text { sgp39 } \\
+\mathrm{IL} 4+\mathrm{IL} 10\end{array}$ \\
\hline \multicolumn{5}{|c|}{ Neonates } \\
\hline 1 & $<20$ & $<20$ & $45 \pm 4.9$ & $74 \pm 7.7$ \\
\hline 2 & $<20$ & $<20$ & $59 \pm 2.8$ & $416 \pm 54.5$ \\
\hline 3 & $<20$ & $<20$ & $74 \pm 7.5$ & $249 \pm 2.0$ \\
\hline 4 & $<20$ & $<20$ & $110 \pm 8.5$ & $128 \pm 2.0$ \\
\hline 5 & $<20$ & $<20$ & $51 \pm 1.4$ & $494 \pm 36.1$ \\
\hline 6 & $<20$ & $<20$ & $183 \pm 12.0$ & $297 \pm 15.5$ \\
\hline 7 & $<20$ & $<20$ & $50 \pm 5.2$ & $333 \pm 41.0$ \\
\hline \multicolumn{5}{|l|}{ Adults } \\
\hline 1 & $91 \pm 3.7$ & $989 \pm 124.1$ & $115 \pm 22.5$ & $745 \pm 85.5$ \\
\hline 2 & $132 \pm 19.8$ & $2285 \pm 756.5$ & $465 \pm 108.2$ & $1093 \pm 301.9$ \\
\hline
\end{tabular}

Purified B cells were cultured with sgp39 (1:4) and IL-4 (100 U/ml) and/or IL-10 $(10 \mathrm{ng} / \mathrm{ml})$ for $12 \mathrm{~d}$. IgG concentrations (nanograms per millilters) in culture supernatants were measured by ELISA with a lower limit of detectability of $20 \mathrm{ng} / \mathrm{ml}$. Results shown are mean $\pm S D$ of triplicate cultures.

cells convert into $\mathrm{CD}_{4} 5 \mathrm{RO}^{+}$cells with in vitro priming and acquire the capacity to produce IFN- $\gamma$, IL-4, and other lymphokines that are produced by freshly isolated adult $\mathrm{CD}^{+}$ $\mathrm{CD}^{2} 5 \mathrm{RO}^{+}$memory $\mathrm{T}$ cells, but not by naive $\mathrm{T}$ cells $(4-7$, 39-41).

To test if the lack of antigen exposure is involved in the inability of neonatal T cells to express CD40 ligand after activation with PMA and ionomycin, we used an in vitro priming culture system. After priming culture, the percentage of neonatal $T$ cells expressing CD40 ligand after activation increased threefold from 15 to $47 \%$ (Fig. $6, B$ and $D$ ) comparable with freshly isolated (50\%, Fig. $6 \mathrm{~A}$ ) or primed adult T cells (57\%, Fig. 6 C). Furthermore, we observed that primed neonatal $\mathrm{T}$ cells exhibited helper activity comparable with adult $\mathrm{T}$ cells (Fig. 7). Consistent with these findings is the observation by Clement et al. (35) that neonatal CD45RA ${ }^{+} \mathrm{CD}^{+}{ }^{+} \mathrm{T}$ cells, if activated with PHA and cultured in the presence of $\mathrm{IL}-2$, acquire the helper cell function of inducing Ig production by B cells. Because CD40 ligand has been shown to induce $B$ cell activation and Ig synthesis via CD40 in the presence of cytokines, our data suggest that acquisition of this helper activity may, in part, be due to the enhanced expression of CD40 ligand by primed neonatal $\mathrm{T}$ cells. These results also suggest that decreased expression of CD40 ligand by neonatal T cells, like the decreased expression of IL-4 and IFN- $\gamma(6,7)$, is due to the lack of "education" by exposure to exogenous antigen.

To assess neonatal B cell function, we cultured purified B cells in the presence of sgp39, the physiologic ligand of CD40, and cytokines. The combination of sgp 39 and IL-4 induced proliferation and IgE production in amounts comparable with adult B cells and the production of a modest amount of IgG. In the presence of sgp39 and IL-10, neonatal and adult B cells produced IgM in similar amounts. However, if analyzed for IgG and IgA, culture supernatants of neonatal B cells exposed to sgp39 and IL-10 had consistently lower and often undetectable levels relative to those of adult B cells. These results are 
consistent with the fact that neonatal B cells are mostly uncommitted $\operatorname{IgM}^{+} \operatorname{IgD}^{+}$cells (1), and that IL-10, at the dose used, has little capacity to induce Ig class switching (15), while IL-4 induces switching potently to IgE and modestly to IgG production $(12,14)$. Similar results were reported by Splawski et al. (2) using anti-CD3-activated adult T cells, which induced normal IgM production, but very little IgA and IgG production by neonatal $\mathrm{B}$ cells. This observation may be simply explained by the costimulatory effect of CD40 ligand and IL-4 or IL-10, since anti-CD3-activated adult $\mathrm{T}$ cells express CD40 ligand and secrete various cytokines including IL-4 and IL-10 (31, 42, 43 ), though other cytokines and adhesion molecules expressed by activated $\mathrm{T}$ cells may also contribute to the $\mathrm{Ig}$ production induced by anti-CD3-activated $T$ cells. The recent finding that cord blood B-cells, when stimulated with anti-CD40 mAb89 and irradiated $\mathrm{CDw} 32 \mathrm{~L}$ cells in the presence of high concentrations of IL-10, can secrete $\mathrm{IgM}, \mathrm{IgG}_{1}$, and $\mathrm{IgG}_{3}$ in quantities similar to adult $\operatorname{sIgD}^{+} \mathrm{B}$ cells (44) further supports our hypothesis that neonatal B cells, though uncommitted, can be activated to produce $\mathrm{Ig}$ of different isotypes.

These studies demonstrate that neonatal $\mathrm{T}$ cells express diminished amounts of CD40 ligand and exhibit depressed helper activity even if they are maximally stimulated with PMA and ionomycin, while neonatal B cells were able to produce immunoglobulins and undergo isotype switching if cultured in the presence of cytokines and CD40 ligand (sgp39). These results suggest that decreased expression of CD40 ligand by neonatal $\mathrm{T}$ cells is an important factor contributing to B cell immaturity, resulting in diminished IgG production in the neonate. Consistent with this hypothesis is the finding that patients with the hyper IgM syndrome, who fail to switch from IgM to other isotypes, have genetically defective CD40 ligand (16, 22-25). Furthermore, a subset of patients with common variable immunodeficiency and decreased serum Ig has depressed CD40 ligand expression (26). These findings indicate that CD40 ligand plays an important role in the induction of $B$ cell maturation in vivo. It is of interest that both CD40 ligand and IL-4, which are important for Ig class switching, are expressed or produced in decreased levels by neonatal $\mathrm{T}$ cells. Together, these observations suggest that immaturity of neonatal $\mathrm{T}$ cells, as manifested by decreased expression of CD40 ligand and decreased production of cytokines (e.g., reduced IL- 4 and IFN- $\gamma$ ), is the major cause of the functional B cell immaturity in neonates. Like the production and secretion of cytokines, the ability to express CD40 ligand could be induced by priming of neonatal T cells, suggesting that the lack of exposure to exogenous antigens is a principal cause of this immaturity.

\section{Acknowledgments}

This study was supported by National Institutes of Health grants HD17427 (to H. D. Ochs), HD-18184 (C. B. Wilson), AI24578 (C. B. Wilson), AI01117 (L. A. Penix), AI26940 (D. B. Lewis), Department of Energy grant DE-F006-86-ER60409 (A. Aruffo and C. P. Edwards); a grant from Pediatric AIDS Foundation (C. B. Wilson and L. A. Penix), and grant 6-93-0116 from the March of Dimes Birth Defects Foundation (H. D. Ochs).

\section{References}

1. Gathings, W. E., H. Kubagawa, and M. D. Cooper. 1981. A distinctive pattern of B cell immaturity in perinatal humans. Immunol. Rev. 57:107-126.
2. Splawski, J. B., D. F. Jelinek, and P. E. Lipsky. 1991. Delineation of the functional capacity of human neonatal lymphocytes. J. Clin. Invest. 87:545-553.

3. Miyawaki, T., H. Kubagawa, J. L. Butler, and M. D. Cooper. 1988. Ig isotypes produced by EBV-transformed $B$ cells as a function of age and tissue distribution. J. Immunol. 140:3887-3892.

4. Sanders, M. E., M. W. Makgoba, S. O. Sharrow, D. Stephany, T. A. Springer, H. A. Young, and S. Shaw. 1988. Human memory T lymphocytes express increased levels of three cell adhesion molecules (LFA-3, CD2, and LFA1) and three other molecules (UCHL1, CDw29, and Pgp-1) and have enhanced IFN-gamma production. J. Immunol. 140:1401-1407.

5. Swain, S. L., L. M. Bradley, M. Croft, S. Tonkonogy, G. Atkins, A. D. Weinberg, D. D. Duncan, S. M. Hedrick, R. W. Dutton, and G. Huston. 1991 Helper T-cell subsets: phenotype, function and the role of lymphokines in regulating their development. Immunol. Rev. 123:115-144.

6. Lewis, D. B., C. C. Yu, J. Meyer, B. K. English, S. J. Kahn, and C. B. Wilson. 1991. Cellular and molecular mechanisms for reduced interleukin 4 and interferon- $\gamma$ production by neonatal T cells. J. Clin. Invest. 87:194-202.

7. Ehlers, S., and K. A. Smith. 1991. Differentiation of T cell lymphokine gene expression: the in vitro acquisition of T cell memory. J. Exp. Med. 173:2536.

8. Clark, E. A., and P. J. L. Lane. 1991. Regulation of human B-cell activation and adhesion. Annu. Rev. Immunol. 9:97-127.

9. Clark, E. A., and J. A. Ledbetter. 1986. Activation of human B cells mediated through two distinct cell surface differentiation antigens, Bp35 and Bp50. Proc. Natl. Acad. Sci. USA. 83:4494-4498.

10. Lane, P., T. Brocker, S. Hubele, E. Padovan, A., Lanzavecchia, and F. McConnell. 1993. Soluble CD40 ligand can replace the normal T cell-derived CD40 ligand signal to B cells in T cell-dependent activation. J. Exp. Med. 177:1209-1213.

11. Shapira, S. K., D. Vercelli, H. H. Jabara, S. M. Fu, and R. S. Geha. 1992. Molecular analysis of the induction of immunoglobulin E synthesis in human B cells by interleukin 4 and engagement of CD40 antigen. J. Exp. Med. 175:289292.

12. Jabara, H. H., S. M. Fu, R. S. Geha, and D. Vercelli. 1990. CD40 and IgE: synergism between anti-CD40 monoclonal antibody and interleukin 4 in the induction of IgE synthesis by highly purified human B cells. J. Exp. Med 172:1861-1864.

13. Rousset, F., E. Garcia, and J. Banchereau. 1991. Cytokine-induced proliferation and immunoglobulin production of human B lymphocytes triggered through their CD40 antigen. J. Exp. Med. 173:705-710.

14. Zhang, K., E. A. Clark, and A. Saxon. 1991. CD40 stimulation provides an IFN-gamma-independent and IL-4-dependent differentiation signal directly to human B cells for IgE production. J. Immunol. 146:1836-1842.

15. Defrance, T., B. Vanbervliet, F. Brière, I. Durand, F. Rousset, and J. Banchereau. 1992. Interleukin 10 and transforming growth factor beta cooperate to induce anti-CD40-activated naive human B cells to secrete immunoglobulin A. J. Exp. Med. 175:671-682.

16. Aruffo, A., M. Farrington, D. Hollenbaugh, X. Li, A. Milatovich, S., Nonoyama, J. Bajorath, L. S. Grosmaire, R. Stenkamp, M. Neubauer, et al. 1993. The CD40 ligand, gp39, is defective in activated T cells from patients with $\mathrm{X}$ linked hyper-IgM syndrome. Cell. 72:291-300.

17. Maliszewski, C. R., K. Grabstein, W. C. Fanslow, R. Armitage, M. K Spriggs, and T. A. Sato. 1993. Recombinant CD40 ligand stimulation of murine B cell growth and differentiation: cooperative effects of cytokines. Eur. J. Immunol. 23:1044-1049.

18. Riggs, J. E., R. S. Stowers, and D. E. Mosier. 1991. Adoptive transfer of neonatal $\mathrm{T}$ lymphocytes rescues immunoglobulin production in mice with severe combined immune deficiency. J. Exp. Med. 173:265-268.

19. Armitage, R. J., W. C. Fanslow, L. Strockbine, T. A. Sato, K. N. Clifford, B. M. Macduff, D. M. Anderson, S. D. Gimpel, T. Davis-Smith, C. R. Maliszewski et al. 1992. Molecular and biological characterization of a murine ligand for CD40. Nature (Lond.). 357:80-82.

20. Lane, P., A. Traunecker, S. Hubele, S. Inui, A. Lanzavecchia, and D. Gray. 1992. Activated human T cells express a ligand for the human B cellassociated antigen CD40 which participates in T cell-dependent activation of B lymphocytes. Eur. J. Immunol. 22:2573-2578.

21. Noelle, R. J., M. Roy, D. M. Shepherd, I. Stamenkovic, J. A. Ledbetter, and A. Aruffo. 1992. A 39-kDa protein on activated helper T cells binds CD40 and transduces the signal for cognate activation of B cells. Proc. Natl. Acad. Sci. USA. 89:6550-6554.

22. Allen, R. C., R. J. Armitage, M. E. Conley, H. Rosenblatt, N. A. Jenkins, N. G. Copeland, M. A. Bedell, S. Edelhoff, C. M. Disteche, D. K. Simoneaux, et al. 1993. CD40 ligand gene defects responsible for X-linked hyper-IgM syndrome. Science (Wash. DC). 259:990-993.

23. Korthäuer, U., D. Graf, H. W. Mages, F. Brière, M. Padayachee, S. Malcolm, A. G. Ugazio, L. D. Notarangelo, R. J. Levinsky, and R. A. Kroczek. 1993. Defective expression of T-cell CD40 ligand causes X-linked immunodeficiency with hyper-IgM. Nature (Lond). 361:539-541.

24. DiSanto, J. P., J. Y. Bonnefoy, J. F. Gauchat, A. Fischer, and G. de-Saint- 
Basile. 1993. CD40 ligand mutations in X-linked immunodeficiency with hyperIgM. Nature (Lond.). 361:541-543.

25. Fuleihan, R., N. Ramesh, R. Loh, H. Jabara, F. S. Rosen, T., Chatila S. M. Fu, I. Stamenkovic, and R. S. Geha. 1993. Defective expression of the CD49 ligand in X chromosome-linked immunoglobulin deficiency with norma or elevated IgM. Proc. Natl. Acad. Sci. USA. 90:2170-2173.

26. Farrington, M., L. S. Grosmaire, S. Nonoyama, S. H. Fischer, D. Hollenbaugh, J. A. Ledbetter, R. J. Noelle, A., Aruffo, and H. D. Ochs. 1994. CD40 ligand expression is defective in a subset of patients with common variable immunodeficiency. Proc. Natl. Acad. Sci USA. 91:1099-1103.

27. Pelllegrino, M. A., S. Ferrone, M. P. Dierich, and R. A. Reisfeld. 1975 Enhancement of sheep red blood cell human lymphocyte rosette formation by the sulf hydryl component 2-amino ethylisothiouronium bromide. Clin. Immunol. Immunopathol. 3:324-333.

28. Thiele, D. L., and P. E. Lipsky. 1985. Modulation of human natura killer cell function by L-leucine methyl ester: monocyte-dependent depletion from human peripheral blood mononuclear cells. J. Immunol. 134:786-793.

29. Lewis, D B., A. Larsen, and C. B. Wilson. 1986. Reduced interferongamma mRNA levels in human neonates. J. Exp. Med. 163:1018-1023.

30. Zielger, S. F., F. Ramsdell, K. A. Hjerrild, R. J. Armitage, K. H. Grabstein K. B. Hennen, T. Farrah, W. C. Fanslow, E. M. Shevach, and M. R. Alderson 1993. Molecular characterization of the early activation antigen CD69: a type II membrane glycoprotein related to a family of natural killer cell activation antigens. Eur. J. Immunol. 23:1643-1648.

1. Lewis, D. B., K. S. Prickett, A. Larsen, K. Grabstein, M. Weaver, and C. B. Wilson. 1988. Restricted production of interleukin 4 by activated human T cells. Proc. Natl. Acad. Sci. USA. 85:9743-9747.

32. Hollenbaugh, D., L. S. Grosmaire, C. D. Kullas, N. J. Chalupny, S. Braesch-Andersen, R. J. Noelle, I. Stamenkovic, J. A. Ledbetter, and A. Aruffo 1992. The human T cell antigen gp39, a member of the TNF gene family, is a ligand for the CD40 receptor: expression of a soluble form of gp39 with B cell co-stimulatory activity. EMBO (Eur. Mol. Biol. Organ. ) J. 11:4313-4321.

33. Tedder, T. F., L. T. Clement, and M. D. Cooper. 1985. Human lymphocyte differentiation antigens HB-10, HB-11. I. Ontogeny of antigen expression. J. Immunol. 134:2983-2988.
34. Hayward, A. R., R. J. Lee, and P. C. L. Beverley. 1989. Ontogeny of expression of UCHL1 antigen on $\mathrm{TCR}^{+}(\mathrm{CD} 4 / 8)$ and $\mathrm{TCR} \delta^{+} \mathrm{T}$ cells. Eur. $J$. Immunol. 19:771-773.

35. Clement, L. T., P. E. Vink, and G. E. Bradley. 1990. Novel immunoregulatory functions of phenotypically distinct subpopulations of $\mathrm{CD}^{+}$cells in the human neonate. J. Immunol. 145:102-108.

36. Lee, W. T., and E. S. Vitetta. 1991. Virgin T cells do not provide help for antigen-specific B cells in the absence of IL-4, IL-5, and IL-6. Int. Immunol. 3:907-926.

37. Rothstein, D. M., A. Yamada, S. F. Schlossman, and C. Morimoto. 1991 Cyclic regulation of CD45 isoform expression in a long term human CD4 ${ }^{+}$ $\mathrm{CD}^{2} 5 \mathrm{RA}^{+} \mathrm{T}$ cell line. J. Immunol. 146:1175-1183.

38. Lee, W. T., X. M. Yin, and E. S. Vitetta. 1990. Functional and ontogenetic analysis of murine CD45R ${ }^{\text {hi }}$ and $C D 45 \mathrm{R}^{10} \mathrm{CD} 4{ }^{+} \mathrm{T}$ cells. J. Immunol. 144:32883295.

39. Budd, R. C., J. C. Cerottini, and H. R. MacDonald. 1987. Selectively increased production of interferon- $\gamma$ by subsets of $\mathrm{Lyt}-2^{+}$and $\mathrm{L3T} 4^{+} \mathrm{T}$ cells identified by expression of Pgp-1. J. Immunol. 138:3583-3586.

40. Melvin, A. J., and D. B. Lewis. 1993. Hypomethylation of the human interferon-gamma gene during $\mathrm{T}$ cell development. J. Immunol. 150:129a. (Abstr.)

41. Wilson, C. B., L. Penix, A. Melvin, and D. B. Lewis. 1993. Lymphokine regulation and the role of abnormal regulation in immunodeficiency. Clin. Immunol. Immunopathol. 67:S25-S32.

42. Spriggs, M. K., R. J. Armitage, L. Strockbine, K. N. Clifford, B. M. Macduff, T. A. Sato, C. R. Maliszewski, and W. C. Fanslow. 1992. Recombinan human CD40 ligand stimulates B cell proliferation and immunoglobulin E secretion. J. Exp. Med. 176:1543-1550.

43. Yssel, H., R. de-Waal-Malefyt, M. G. Roncarolo, J. S. Abrams, R. Lahesmaa, H. Spits, and J. E. de-Vries, 1992. IL-10 is produced by subsets of human $\mathrm{CD}^{+} \mathrm{T}$ cells clones and peripheral blood T cells. J. Immunol. 149:2378-2384.

44. Brière, F., C. Servet-Delprat, J.-M. Bridon, J.-M. Saint-Remy, and J. Banchereau. 1994. Human interleukin 10 induces naive surface immunoglobulin $\mathrm{D}^{+}\left(\mathrm{sIgD}^{+}\right) \mathrm{B}$ cells to secrete IgG1 and IgG3. J. Exp. Med. 179:757-762. 